\title{
Vegetative Phase Transition and Corn Borer Resistance of shrunken2 versus sugary1 Sweet Corn Near-isogenic Inbred Lines
}

\author{
Pedro Revilla ${ }^{1}$ \\ Misión Biológica de Galicia, Spanish Council for Scientific Research, Apartado 28, 36080 Pontevedra, \\ Spain \\ William F. Tracy \\ Department of Agronomy, University of Wisconsin-Madison, Madison, WI 53706

\begin{abstract}
Pilar Soengas, Bernardo Ordás, Amando Ordás, and Rosa Ana Malvar
Misión Biológica de Galicia, Spanish Council for Scientific Research, Apartado 28, 36080 Pontevedra, Spain
\end{abstract}

\begin{abstract}
ADDITIONAL INDEX WORDS. Zea mays, vegetative phases, Ostrinia nubilalis, Sesamia nonagrioides
ABSTRACT. The genes sugaryl (su1) and shrunken2 (sh2) are commonly used to produce sweet and super-sweet corn (Zea mays L.), respectively. In this work we compare corn borer [european corn borer (ECB) (Ostrinia nubilalis Hbn.) and pink stem borer (PSB) (Sesamia nonagrioides Lef.)] susceptibility in seven pairs of sul and sh2 near-isogenic sweet corn inbreds (101t, C23, C40, C68, Ia453, Ia5125, and P39) and the relationship between corn borer resistance and vegetative phase transition. The seven pairs of near-isogenic inbreds were evaluated under corn borer infestation during 3 years in northwestern Spain. Differences among inbreds were significant for most of the traits, although resistance was partial. Ia5125sul and C40sul were the most resistant inbreds. Differences between a few pairs of near-isogenic sul and sh2 strains were significant for some vegetative phase change and corn borer damage-related traits. Generally sul strains flowered earlier, had a shorter juvenile phase, fewer PSB, and more ECB larvae than sh2 strains. However sul and sh2 strains did not differ significantly for most traits related to phase transition and corn borer damage; notably ear damage was not significantly different between $s u 1$ and $s h 2$ strains. These results suggest that theoretical and practical results of sweet corn (sugary1) breeding for corn borer resistance could be capitalized for super-sweet corn (shrunken2) breeding.
\end{abstract}

Sweet corn varieties used in temperate areas are primarily homozygous for sugaryl (sul), while super-sweet corn is homozygous for shrunken $2(s h 2)$ and is currently the second most widely used endosperm type after sul (Tracy, 2000). There are several differences between sul and sh2, with sweetness the most evident for consumers (Tracy, 2000). From the agronomic perspective, $s h 2$ has worse seed quality (germination and field emergence), cold tolerance, root and stalk quality, ear type, plant color, husk protection, and disease resistance than sul, although these statements have not always been adequately tested (Tracy, 1997).

The main insect pest of sweet corn in temperate areas is corn borer [european corn borer (ECB) and other Lepidopteran species such as pink stem borer (PSB)] (Cordero et al., 1998; Malvar et al., 2002). Even in the Mediterranean area, where PSB is the major insect pest, ECB is still one of the most common insects in sweet corn ears (Velasco et al., 2002).

Variability for resistance to ECB among sweet corn inbreds has been known since the 1970s (Andrew and Carlson, 1976a). Resistance to ECB and PSB has been studied among sugaryl genotypes (Malvar et al., 2002; Velasco et al., 1999, 2002). The inheritance of corn borer resistance in sweet corn is partial and

Received for publication 1 July 2003. Accepted for publication 24 June 2004. Research supported by the National Plan of Research and Development of Spain (Project Cod. AGL2000-0944) and Excma. Diputación Provincial de Pontevedra, Spain.

${ }^{1}$ To whom reprint requests should be addressed: phone: 34986 854800; fax 34 986 841362; E-mail: previlla@mbg.cesga.es mainly additive (Velasco et al., 2002). However, little has been published about the resistance of $s h 2$ sweet corn to corn borers. In order to know if the knowledge and germplasm developed for improving corn borer resistance in sul sweet corn can be useful for improving super-sweet (sh2) corn, it is essential to determine if $s h 2$ affects corn borer resistance, compared to sul. For example, variability for antixenosis among sweet corn and popcorn has been inversely associated to sweetness, lack of pubescence, and earliness (Andrew and Carlson, 1976b).

Besides genetic factors, plant age and environment affect corn borer damage (Gardner et al., 2001). Plant age and pubescence are strongly affected by variation in vegetative phases. Maize has two vegetative phases, juvenile and adult. Juvenile and adult leaves, internodes, and axillary buds differ in anatomy and physiology (Bongard-Pierce et al., 1996; Lawson and Poethig, 1995; Poethig, 1988). Compared to juvenile leaves, adult leaves are wider and longer, have trichomes and lack epicuticular wax; adult nodes do not produce adventitious roots, and axillary buds may develop into ear primordia. A short juvenile phase has been associated with resistance to european corn borer, fall armyworm (Spodoptera frugiperda J.E. Smith), and southwestern corn borer (Diatraea grandiosella Dyar.) in maize because adult tissue is more resistant to insects than juvenile tissue (Abedon et al., 1999; Williams et al., 1998, 2000). However nothing has been published about vegetative phase transition in $s h 2$ germplasm.

Our objective was to compare relative susceptibility and vegetative phase transition between sul and sh2 near-isogenic sweet corn inbreds, in order to indicate the applicability of $s u l$ research results to $s h 2$ breeding. 


\section{Materials and Methods}

The sweet corn inbred lines 101t, C23, C40, C68, Ia453, Ia5125, and P39 were used by Soberalske and Andrew (1978, 1980) to develop near-isogenic inbred lines homozygous for either sugaryl or shrunken2. The 14 near-isogenic inbreds were evaluated under corn borer infestation during 2000, 2001, and 2002 at Pontevedra (northwestern Spain). Trials followed a randomized complete-block design with four replications. Each plot consisted of two rows with 15 plants per row. Plants were spaced $0.21 \mathrm{~m}$ apart and rows were spaced $0.80 \mathrm{~m}$, corresponding to a density of $\approx 60,000$ plants/ha. Hills were over planted and thinned after emergence.

After half of the plants in each trial had flowered, five plants per plot were artificially infested with two ECB egg masses of $\approx 40$ eggs. One of the egg masses was laid between the stem and the third leaf above the main ear, and the other mass at the third leaf below the main ear, in order to assure infestation in both juvenile and adult stem. ECB eggs were supplied by the Centre de Recherches de Poitou-Charentes (Institut National de la Recherche Agronomique, Le Magneraud, France). Infestation was made with ECB because this is a general pest in temperate regions worldwide, but natural infestation with PSB in Pontevedra is so high that usually $100 \%$ of the plants are infested by harvest (Cordero et al., 1998). At harvest time (October) in an adjacent field, $95 \%$ of maize plants were naturally infested. There were 0.8 PSB larvae/stem, and 0.2 ECB larvae/stem, averaged over 2000, 2001, and 2002.

In each plot, the following data were taken during plant development: days to pollen and silking, and number of adult leaves (without epicuticular wax) below the main ear. At dry seed stage, the ears infested with ECB were harvested. Main ear damage was rated according to a linear scale from 1 (= completely damaged ear) to 9 (= nondamaged ear). The infested stems were divided in juvenile and adult phases by the node corresponding to the last leaf with epicuticular wax. The proportion of juvenile stem was calculated as the ratio between length of juvenile stem and total length. In each part of the stem, the following traits were measured: proportion of adult and juvenile stem damaged (\%), and number of PSB larvae and number of ECB larvae per meter of adult and juvenile stem.

Analyses of variance (ANOVAs) were made, including as sources of variation years, replications within years, genes ( $\mathrm{sul}$ and sh2), inbred lines (101t, C23, C40, C68, Ia453, Ia5125, and P39), and the appropriate interactions. All sources of variation, except genes, inbred lines, and their appropriate interactions were considered random. Since near-isogenic inbreds are actually different genotypes, ANOVAs were performed, including years, replications within years, the 14 genotypes (101tsu1, C23 sul, C40 su1, C68 sul, Ia453 su1, Ia5125 su1, P39 sul, 101tsh2, C23 sh2, C40 sh2, C68 sh2, Ia453 sh2, Ia5125 sh2, and P39 sh2), and the appropriate interactions. Besides, for the three traits that were recorded separately in juvenile and in adult tissue (stem damaged and number of PSB and ECB larvae), further ANOVAs were made using vegetative phase (juvenile and adult) as an additional source of variation. Therefore, the sources of variation in the ANOVAs for damage-related traits were years, replications within years, genes, vegetative phase (juvenile vs. adult), inbred lines, and the appropriate interactions. All sources of variation, except vegetative phase, genes, inbred lines, and their appropriate interactions were considered random. All analyses were performed using the SAS program (SAS Inst., Cary, N.C.).

\section{Results and Discussion}

The combined ANOVAs, considering seven inbred lines and two genes per inbred, showed significant year $\times$ gene $\times$ inbred line and year $\times$ gene interactions for four of the 13 traits (Table $1)$. The year $\times$ inbred line and the gene $\times$ inbred line interactions were not significant for any trait. Genes did not differ significantly for any trait and inbreds differed for four traits.

ANOVA considering the 14 genotypes (seven pairs of nearisogenic inbreds) showed significant year $\times$ inbred interactions for half of the traits (data not shown). Inbreds were significantly different for days to pollen and silking, adult leaves, and PSB larvae in juvenile and adult stem, and for ECB larvae per ear (Table 2). Differences between sul and sh2 isogenic pairs of each inbred were nonsignificant for most traits, particularly for ear-related traits (Table 2).

The $s u l$ inbreds tended to have fewer days to pollen and silking than their corresponding sh2 versions; these differences were significant for four of the seven pairs of isogenic inbreds (Table 2 ). Concerning phase transition-related traits, the number of adult leaves below the main ear did not follow any particular pattern among sul and sh 2 inbreds, and the only significant difference was for $\mathrm{C} 23$, for which the $s u 1$ version had more adult leaves below the main ear than the sh2 version (Table 2). The ANOVAs for stem damage, using vegetative phase as an additional source of variation, showed significant differences between genes for PSB larvae (Table 3). Differences between juvenile and adult phases were not significant for any trait. Within the juvenile and adult phases, sul and sh2 did not differ significantly for stem damagerelated traits. When means across inbreds and vegetative phases were compared, sh2 had similar tunnel length to sul.

Comparisons among the 14 inbreds showed that inbreds Ia5125sul and C40sul had lower proportion of tunnels in adult stem than 101tsul, 101tsh2, C23sul, and P39su1. Velasco et al. (1999) identified Ia5125 as one of the inbreds less damaged by PSB and P39 as one of the most damaged inbreds. These authors also concluded that resistance of sweet corn inbreds to PSB was partial and needed to be improved. Velasco et al. (2002) also found that differences in resistance among sweet corn inbreds for ECB were significant although not very clear, because most inbreds had intermediate resistance. Significant differences were found between sul and sh2 strains of Ia453 and Ia5125 for number of PSB larvae in juvenile stem, and between strains of C40 for number of PSB larvae in adult stem, but other differences between pairs were nonsignificant (Table 2). However some trends could be observed, particularly sul strains had fewer PSB and more ECB larvae than sh 2 strains, and this relationship was similar for juvenile and adult stem (Table 3 ). The number of PSB larvae per meter of juvenile stem varied from zero in P39sh2 to 5.8 in I5125sh2 (Table 2). These data suggest that a reduction in juvenile tissue could result in fewer larvae per stem. However, an alternative explanation is that the proportion of juvenile tissue in fully developed plants is so small that the chances of finding larvae are very low. Differences among inbreds for number of larvae in adult stem were not important, and only C40sh2 had significantly more larvae than any other inbred (Table 2). Nevertheless, the number of larvae cannot be used as an indication of resistance because larvae migrate and their abundance depends on the appropriate developmental stage of the plant.

In conclusion, sul inbreds flower earlier than sh2 inbreds. Some relationship between corn borer damage, phase transition, and sweet corn genes (sh2 or sul) can be postulated, although 


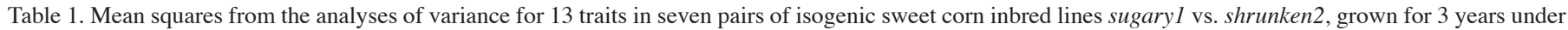
artificial infestation with european corn borer (ECB) and natural infestation with pink stem borer (PSB) in northwestern Spain.

\begin{tabular}{|c|c|c|c|c|c|c|c|c|c|c|c|c|c|c|}
\hline \multirow[b]{2}{*}{ Genotype } & \multirow[b]{2}{*}{$\mathrm{df}^{\mathrm{z}}$} & \multirow{2}{*}{$\begin{array}{l}\text { Days to } \\
\text { pollen }\end{array}$} & \multirow{2}{*}{$\begin{array}{l}\text { Days to } \\
\text { silking }\end{array}$} & \multirow{2}{*}{$\begin{array}{l}\text { Adult } \\
\text { leaves }\end{array}$} & \multirow{2}{*}{$\begin{array}{c}\text { Juvenile } \\
\text { stem }\end{array}$} & \multicolumn{3}{|c|}{ Juvenile stem } & \multicolumn{3}{|c|}{ Adult stem } & \multicolumn{3}{|c|}{ Ear } \\
\hline & & & & & & Tunnels & PSB & $\overline{\mathrm{ECB}}$ & Tunnels & PSB & $\overline{\mathrm{ECB}}$ & Damage & PSB & $\mathrm{ECB}$ \\
\hline Years (Y) & 2 & 126.95 & 172.33 & 7.33 & 703.43 & 3995.77 & $1.77^{* * *}$ & 33.58 & 4028.1 & 0.71 & 11.53 & 72.78 & 1.56 & 0.038 \\
\hline Reps. / Y & 7 & $20.74^{*}$ & $28.40^{*}$ & 0.20 & 62.83 & $322.90^{* *}$ & 3.71 & 10.01 & $696.9^{* *}$ & 6.18 & 0.11 & $5.37^{* *}$ & $1.13^{*}$ & $0.127^{*}$ \\
\hline Gene $(\mathrm{G})$ & 1 & 604.30 & 580.95 & 3.05 & 412.35 & 678.73 & 35.82 & 146.29 & 5.2 & 38.77 & 0.70 & 0.08 & 0.19 & 0.050 \\
\hline $\mathrm{Y} \times \mathrm{G}$ & 2 & $103.21^{*}$ & $105.95^{*}$ & $2.70^{*}$ & 300.51 & 164.08 & 2.05 & 46.16 & $477.8^{*}$ & 2.44 & 3.77 & 3.52 & 0.04 & 0.114 \\
\hline Line (L) & 6 & 61.25 & 65.79 & $9.06^{* * *}$ & $241.28^{*}$ & 2263.99 & 13.97 & 18.32 & $347.4^{*}$ & 16.76 & 3.87 & 7.83 & 0.32 & $0.118^{*}$ \\
\hline $\mathrm{Y} \times \mathrm{L}$ & 12 & 61.38 & 31.75 & 1.58 & 55.92 & 989.12 & 4.92 & 37.63 & 111.0 & 9.95 & 3.57 & 2.90 & 0.58 & 0.031 \\
\hline $\mathrm{G} \times \mathrm{L}$ & 6 & 16.22 & 7.64 & 1.80 & 81.77 & 455.84 & 10.64 & 40.07 & 167.3 & 23.57 & 3.46 & 3.10 & 0.12 & 0.099 \\
\hline $\mathrm{Y} \times \mathrm{G} \times \mathrm{L}$ & 12 & $19.41^{*}$ & 19.66 & 0.71 & 146.34 & 1103.39 & 6.92 & 35.52 & 97.5 & $8.74^{*}$ & $3.23^{*}$ & $5.85^{* *}$ & 0.57 & 0.034 \\
\hline Error & 93 & 9.61 & 10.97 & 0.70 & 107.73 & 3701.56 & 4.12 & 38.75 & 143.4 & 3.73 & 0.35 & 1.25 & 0.46 & 0.056 \\
\hline
\end{tabular}

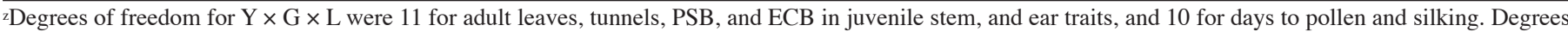

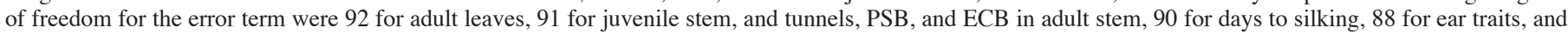
58 for tunnels, PSB, and ECB in juvenile stem.

*** Significant at $P=0.05$ and 0.01 , respectively

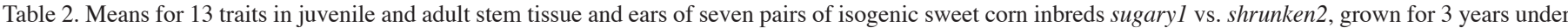
artificial infestation with european corn borer (ECB) and intense natural infestation with pink stem borer (PSB) in northwestern Spain.

\begin{tabular}{|c|c|c|c|c|c|c|c|c|c|c|c|c|c|}
\hline \multirow[b]{2}{*}{ Genotype } & \multirow{2}{*}{$\begin{array}{c}\text { Days to } \\
\text { pollen }\end{array}$} & \multirow{2}{*}{$\begin{array}{l}\text { Days to } \\
\text { silking } \\
\text { d) }\end{array}$} & \multirow{2}{*}{$\begin{array}{c}\text { Adult } \\
\text { leaves } \\
\text { (no.) }\end{array}$} & \multirow{2}{*}{$\begin{array}{c}\text { Juvenile } \\
\text { stem } \\
(\%)\end{array}$} & \multicolumn{3}{|c|}{ Juvenile stem } & \multicolumn{3}{|c|}{ Adult stem } & \multicolumn{3}{|c|}{ Ear } \\
\hline & & & & & $\begin{array}{c}\text { Tunnels } \\
(\%)\end{array}$ & $\begin{array}{l}\text { PSB } \\
\text { (larv }\end{array}$ & $\begin{array}{l}\mathrm{ECB} \\
/ \mathrm{m})\end{array}$ & $\begin{array}{c}\text { Tunnels } \\
(\%)\end{array}$ & $\begin{array}{l}\text { PSB } \\
\text { (larv }\end{array}$ & $\begin{array}{l}\mathrm{ECB} \\
/ \mathrm{m})\end{array}$ & $\begin{array}{c}\text { Damage } \\
(1-9)^{\mathrm{z}}\end{array}$ & $\begin{array}{r}\text { PSB } \\
\text { (no }\end{array}$ & $\begin{array}{c}\text { ECB } \\
\text { larvae) }\end{array}$ \\
\hline $101 \mathrm{tsh} 2$ & 77 bcy $^{y}$ & $79 \mathrm{bc}$ & $2.3 \mathrm{def}$ & 17.7 & 62 & $3.1 \mathrm{bc}$ & 0.5 & $33 \mathrm{a}$ & $0.6 \mathrm{~b}$ & 0.6 & 4.8 & 0.33 & $0.04 \mathrm{~cd}$ \\
\hline $101 \mathrm{tsu} 1$ & 72 ef & $73 \mathrm{fg}$ & $1.8 \mathrm{fg}$ & 6.9 & 62 & $0.3 \mathrm{~d}$ & 0.6 & $30 \mathrm{a}$ & $1.1 \mathrm{~b}$ & 0.8 & 4.9 & 0.35 & $0.12 \mathrm{~b}-\mathrm{d}$ \\
\hline $\mathrm{C} 23 \operatorname{sh} 2$ & $76 \mathrm{~cd}$ & $78 \mathrm{~cd}$ & $3.0 \mathrm{~b}-\mathrm{d}$ & 10.3 & 45 & $0.9 \mathrm{~cd}$ & 0.0 & $27 \mathrm{ab}$ & $1.3 \mathrm{~b}$ & 1.8 & 4.5 & 0.08 & $0.33 \mathrm{ab}$ \\
\hline C23sul & $76 \mathrm{~cd}$ & $77 \mathrm{c}-\mathrm{e}$ & $4.1 \mathrm{a}$ & 8.1 & 38 & $0.7 \mathrm{~d}$ & 7.1 & $33 a$ & $1.2 \mathrm{~b}$ & 0.6 & 5.9 & 0.30 & $0.11 \mathrm{~b}-\mathrm{d}$ \\
\hline $\mathrm{C} 40 \operatorname{sh} 2$ & $78 \mathrm{bc}$ & $80 \mathrm{a}-\mathrm{c}$ & $3.9 \mathrm{a}$ & 4.0 & 53 & $0.7 \mathrm{~d}$ & 0.0 & $24 \mathrm{ab}$ & $6.3 \mathrm{a}$ & 0.1 & 6.5 & 0.88 & $0.06 \mathrm{~cd}$ \\
\hline C40su1 & $76 \mathrm{~cd}$ & $78 \mathrm{~b}-\mathrm{d}$ & $3.7 \mathrm{ab}$ & 8.4 & 25 & $2.0 \mathrm{~b}-\mathrm{d}$ & 0.2 & $18 \mathrm{~b}$ & $0.4 \mathrm{~b}$ & 0.7 & 5.6 & 0.25 & $0.41 \mathrm{a}$ \\
\hline C68sh 2 & $80 \mathrm{ab}$ & $81 a b$ & $3.0 \mathrm{~b}-\mathrm{d}$ & 9.2 & 42 & $1.1 \mathrm{~b}-\mathrm{d}$ & 0.0 & $24 \mathrm{ab}$ & $1.2 \mathrm{~b}$ & 0.3 & 6.6 & 0.74 & $0.24 \mathrm{a}-\mathrm{c}$ \\
\hline C68sul & $73 \mathrm{de}$ & $75 \mathrm{~d}-\mathrm{f}$ & $3.6 \mathrm{ab}$ & 4.8 & 33 & $0.2 \mathrm{~d}$ & 2.2 & $24 \mathrm{ab}$ & $0.7 \mathrm{~b}$ & 0.4 & 6.1 & 0.46 & $0.23 \mathrm{a}-\mathrm{c}$ \\
\hline $\mathrm{I} 453 \operatorname{sh} 2$ & $77 \mathrm{bc}$ & $79 a-c$ & $2.0 \mathrm{e}-\mathrm{g}$ & 13.0 & 39 & $3.3 \mathrm{~b}$ & 0.1 & $26 a b$ & $1.0 \mathrm{~b}$ & 0.6 & 6.2 & 0.55 & $0.24 \mathrm{a}-\mathrm{c}$ \\
\hline I453sul & 71 ef & 74 e-g & $2.6 \mathrm{c}-\mathrm{e}$ & 7.7 & 47 & $0.1 \mathrm{~d}$ & 0.7 & $31 \mathrm{a}$ & $1.1 \mathrm{~b}$ & 1.0 & 5.9 & 0.40 & $0.19 \mathrm{a}-\mathrm{d}$ \\
\hline I5125sh2 & $81 \mathrm{a}$ & $82 \mathrm{a}$ & $1.5 \mathrm{fg}$ & 19.4 & 58 & $5.8 \mathrm{a}$ & 0.0 & $27 \mathrm{ab}$ & $1.5 \mathrm{~b}$ & 0.2 & 3.8 & 0.50 & $0.00 \mathrm{~d}$ \\
\hline I5125sul & $79 \mathrm{ab}$ & $80 \mathrm{a}-\mathrm{c}$ & $1.2 \mathrm{~g}$ & 18.9 & 40 & $1.6 \mathrm{~b}-\mathrm{d}$ & 4.2 & $17 \mathrm{~b}$ & $0.3 \mathrm{~b}$ & 0.4 & 4.9 & 0.40 & $0.03 \mathrm{~cd}$ \\
\hline $\mathrm{P} 39 \operatorname{sh} 2$ & $77 \mathrm{bc}$ & $78 \mathrm{~cd}$ & $3.4 \mathrm{a}-\mathrm{c}$ & 7.8 & 32 & $0.0 \mathrm{~d}$ & 1.2 & $26 \mathrm{ab}$ & $1.3 \mathrm{~b}$ & 0.5 & 4.9 & 0.35 & $0.10 \mathrm{~cd}$ \\
\hline P39sul & $70 \mathrm{f}$ & $72 \mathrm{~g}$ & $3.4 \mathrm{ab}$ & 3.1 & 49 & $0.3 \mathrm{~d}$ & 1.6 & $30 \mathrm{a}$ & $0.6 \mathrm{~b}$ & 0.5 & 5.8 & 0.26 & $0.10 \mathrm{~cd}$ \\
\hline $\operatorname{LSD}_{0.05}$ & 3 & 3 & 0.8 & & & 2.3 & & 11 & 1.8 & & & & 0.23 \\
\hline
\end{tabular}

zEar damage was estimated by using the scale $1=$ completely damaged ear to $9=$ no damaged ear.

yMean separation within columns by LSD, $P=0.05$.

Table 3. Means for three corn borer damage-related traits caused by pink stem borer (PSB) and european corn borer (ECB) larvae in juvenile and adult stem tissue and ears of seven pairs of isogenic sweet corn inbreds sugary1 vs. shrunken2, grown for 3 years under artificial infestation with PSB in northwestern Spain.

\begin{tabular}{lllll}
\hline \multirow{2}{*}{ Factor } & Class & $\begin{array}{c}\text { Tunnels } \\
(\%)\end{array}$ & \multicolumn{2}{c}{$\begin{array}{c}\text { PSB } \\
\text { (larvae/m) }\end{array}$} \\
\hline Phase & Juvenile & 44 & 1.4 & 1.5 \\
& Adult & 27 & 1.2 & 0.6 \\
Juvenile & sh2 & 46 & 2.1 & 0.4 \\
& sul & 42 & 0.6 & 2.6 \\
Adult & sh2 & 27 & 1.7 & 0.5 \\
& sul & 26 & 0.8 & 0.6 \\
Gene & sh2 & 36 & $1.9 \mathrm{a}^{\mathrm{z}}$ & 0.5 \\
& sul & 33 & $0.7 \mathrm{~b}$ & 1.5 \\
\hline
\end{tabular}

${ }^{2}$ Mean separation within columns and factors by LSD, $P=0.05$.

environmental effects and interactions were large, reducing significant differences among classes for each of these factors. However, sul and sh2 near-isogenic inbreds do not differ significantly for most of the traits related to phase transition and corn borer damage; particularly ear damage was nonsignificant different between sul and sh 2 inbreds. These results suggest that theoretical and practical results of sweet corn (sugaryl) breeding for corn borer resistance could be capitalized for super-sweet corn (shrunken2) breeding.

\section{Literature Cited}

Abedon, B.G., L.L. Darrah, and W.F. Tracy. 1999. Developmental changes associated with divergent selection for rind penetrometer resistance in the MoSCSSS maize synthetic. Crop Sci. 39:108-114.

Andrew, R.H. and J.R. Carlson, Jr. 1976a. Evaluation of sweet corn inbreds for resistance for european corn borer. J. Amer. Soc. Hort. Sci. 101:97-99.

Andrew, R.H. and J.R. Carlson, Jr. 1976b. Preference differences of egg laying european corn borer adults among maize genotypes. HortScience 11:143.

Bongard-Pierce, D.K., M.M.S. Evans, and R.S. Poethig. 1996. Heteroblastic features of leaf anatomy in maize and their genetic regulation. Intl. J. Plant. Sci. 157:331-340.

Cordero, A., R.A. Malvar, A. Butrón, P. Revilla, P. Velasco, and A. Ordás. 1998. Population dynamics and life-cycle of corn borers in south Atlantic European coast. Maydica 43:5-12.

Gardner, J., M.P. Hoffmann, M.E. Smith, and M.G. Wright. 2001. Influence of plant age and genotype on resistance to european corn borer in sweet corn. Maydica 46:111-116.

Lawson, E.J.R. and R.S. Poethig. 1995. Shoot development in plants: Time for a change. Trends Genet. 11:263-268.

Malvar, R.A., P. Revilla, P. Velasco, M.E. Cartea, and A. Ordás. 2002. 
Insect damage to sweet corn hybrids in the south Atlantic European coast. J. Amer. Soc. Hort. Sci. 127:693-696.

Poethig, R.S. 1988. Heterochronic mutations affecting shoot development in maize. Genetics 119:959-973.

Soberalske, R.M. and R.H. Andrew. 1978. Gene effects on kernel moisture and sugars of near isogenic lines of sweet corn. Crop Sci. 18:743-746.

Soberalske, R.M. and R.H. Andrew. 1980. Gene effects on water soluble polysaccharides and starch of near-isogenic lines of sweet corn. Crop Sci. 20:201-204.

Tracy, W.F. 1997. History, genetics, and breeding of supersweet (shrunken2) corn. Plant Breeding Rev. 14:189-236.

Tracy, W.F. 2000. Sweet corn, p.155-199. In: A.R. Hallauer (ed.). Specialty corns. 2nd ed. CRC, Boca Raton, Fla.
Velasco, P., R.A. Malvar, A. Butrón, P. Revilla, A. Ordás. 1999. Ear feeding resistance of sweet corn inbreds to pink stem borer. J. Amer. Soc. Hort. Sci. 124:268-272.

Velasco, P., P. Revilla, A. Butrón, B. Ordás, A. Ordás, and R.A. Malvar. 2002. Ear damage of sweet corn inbreds and their hybrids under corn borer infestation. Crop Sci. 42:724-729.

Williams, W.P., F.M. Davis, P.M. Buckley, P.A. Hedin, G.T. Baker, and D.S. Luthe. 1998. Factors associated with resistance to fall armyworm (Lepidoptera:Noctuidae) and southwestern corn borer (Lepdidoptera: Crambidae) in corn at different vegetative stages. J. Econ. Entomol. 91:1471-1480.

Williams, W.P., P.M. Buckley, and F.M. Davis. 2000. Vegetative phase change in maize and its association with resistance to fall armyworm. Maydica 45:215-219. 